\title{
Changing the Stage, Grade and Histological Subtypes of Renal Cell Carcinomas during 10 Years Period
}

\author{
Selahattin Çalıșkan, Orhan Koca, Mehmet Akyüz, \\ Metin İshak Öztürk, Muhammet Ihsan Karaman \\ Department of Urology, Haydarpasa Numune Training and Research Hospital, \\ Istanbul, Turkey \\ Received September 6, 2017; Accepted December 5, 2017.
}

Key words: Renal cell carcinoma - Kidney - Carcinoma

\begin{abstract}
Renal cell carcinomas (RCCs) account $80-85 \%$ of all primary renal neoplasms and originate from the renal cortex. The patients who underwent radical or partial nephrectomy for renal tumour in our unit between January 2005 and 2015 were evaluated retrospectively. The patients were divided into two groups; group 1 includes patients who were treated between January 2005 and December 2009, group 2 those from January 2010 to 2015. There were 103 patients in group 1. The patients were between 21 and 89 years with mean age of 61.46 year. Renal cell carcinomas account $83.4 \%$ of the patients, benign renal tumours were $8.7 \%$ and transitional cell carcinomas were $7.7 \%$ of the patients in group 1 . A total of $32.5 \%$ RCCs were classified as pT1a, $24.4 \%$ as pT1b, $15.1 \%$ as $\mathrm{pT} 2 \mathrm{a}, 11.6 \%$ as pT2b, $15.1 \%$ as pT3a and $1.1 \%$ as pT4. There were 202 patients in group 2 and the patients were between 27 and 81 years with mean age of 58.5 year. Renal cell carcinomas comprised the main bulk of the tumours with 182 nephrectomy specimens. According to the pathological classification of RCCs, 51 specimens were found as pT1a, 54 were pT1b, 13 were pT2a, 14 were pT2b, 48 were pT3a and 2 were $\mathrm{pT} 4$. Although, the incidence of small renal masses has been increasing with widespread use of imaging techniques and recent advancements, the proportion of high grade and advanced stage renal tumours increased during the study period.
\end{abstract}

Mailing Address: Selahattin Çalıșkan, MD., FEBU, Bahçelievler Mah. Çamlık Cad. No. 2 Çorum, Turkey; Phone: +905 547846 552;

e-mail: dr.selahattincaliskan@gmail.com 


\section{Introduction}

Renal tumours are the $3^{\text {rd }}$ most common cancer of all urologic tumours and account $3.5 \%$ of all malignancies (Çalıșkan et al., 2014). Renal cell carcinomas originate from the renal cortex that accounts $80-85 \%$ of all primary renal neoplasms (Hashmi et al., 2014). Twenty-five to thirty percent of the patients with renal tumours are asymptomatic and are found on radiological examinations.

\section{Table 1 - TNM classification of renal cell carcinoma}

\begin{tabular}{|c|c|c|c|}
\hline \multicolumn{4}{|c|}{ Primary tumours $(T)$} \\
\hline TX & \multicolumn{3}{|c|}{ primary tumour cannot be assessed } \\
\hline TO & \multicolumn{3}{|c|}{ no evidence of primary tumour } \\
\hline T1 & \multicolumn{3}{|c|}{ tumour $\leq 7 \mathrm{~cm}$ in greatest dimension, limited to the kidney } \\
\hline T1a & \multicolumn{3}{|c|}{ tumour $\leq 4 \mathrm{~cm}$ in greatest dimension, limited to the kidney } \\
\hline T1b & \multicolumn{3}{|c|}{ tumour $>4 \mathrm{~cm}$ but $\leq 7 \mathrm{~cm}$ in greatest dimension, limited to the kidney } \\
\hline T2 & \multicolumn{3}{|c|}{ tumour $>7 \mathrm{~cm}$ in greatest dimension, limited to the kidney } \\
\hline $\mathrm{T} 2 \mathrm{a}$ & \multicolumn{3}{|c|}{ tumour $>7 \mathrm{~cm}$ but $\leq 10 \mathrm{~cm}$ in greatest dimension, limited to the kidney } \\
\hline $\mathrm{T} 2 \mathrm{~b}$ & \multicolumn{3}{|c|}{ tumour $>10 \mathrm{~cm}$, limited to the kidney } \\
\hline T3 & \multicolumn{3}{|c|}{ tumour extends into major veins or perinephric tissues but not into } \\
\hline & \multicolumn{3}{|c|}{ the ipsilateral adrenal gland and not beyond the Gerota fascia } \\
\hline T3a & \multicolumn{3}{|c|}{$\begin{array}{l}\text { tumour grossly extends into the renal vein or its segmental (muscle-containing) } \\
\text { branches, or tumour invades perirenal and/or renal sinus fat but not beyond } \\
\text { the Gerota fascia }\end{array}$} \\
\hline T3b & \multicolumn{3}{|c|}{ tumour grossly extends into the vena cava below the diaphragm } \\
\hline T3c & \multicolumn{3}{|c|}{$\begin{array}{l}\text { tumour grossly extends into the vena cava above the diaphragm } \\
\text { or invades the wall of the vena cava }\end{array}$} \\
\hline $\mathrm{T} 4$ & \multicolumn{3}{|c|}{$\begin{array}{l}\text { tumour invades beyond the Gerota fascia (including contiguous extension } \\
\text { into the ipsilateral adrenal gland) }\end{array}$} \\
\hline \multicolumn{4}{|c|}{ Regional lymph node $(\mathrm{N})$} \\
\hline NX & \multicolumn{3}{|c|}{ regional lymph nodes cannot be assessed } \\
\hline No & \multicolumn{3}{|c|}{ no regional lymph node metastasis } \\
\hline N1 & \multicolumn{3}{|c|}{ metastasis in regional lymph node(s) } \\
\hline N2 & \multicolumn{3}{|c|}{ metastasis in more than 1 regional lymph node(s) } \\
\hline \multicolumn{4}{|c|}{ Distant metastasis $(\mathrm{M})$} \\
\hline MO & \\
\hline M1 & & \multicolumn{2}{|c|}{ distant metastasis } \\
\hline \multicolumn{4}{|c|}{ TNM stage grouping } \\
\hline Stage I & T1 & No & Mo \\
\hline Stage II & $\mathrm{T} 2$ & No & Mo \\
\hline \multirow{2}{*}{ Stage III } & T3 & No & Mo \\
\hline & $\mathrm{T} 1, \mathrm{~T} 2, \mathrm{~T} 3$ & N1 & Mo \\
\hline \multirow{3}{*}{ Stage IV } & $\mathrm{T} 4$ & any $\mathrm{N}$ & Mo \\
\hline & any $\mathrm{T}$ & N2 & Mo \\
\hline & any $\mathrm{T}$ & any $\mathrm{N}$ & M1 \\
\hline
\end{tabular}

Çalıșkan S.; Koca O.; Akyüz M.; Öztürk M. İ.; Karaman M. I. 
There has been an increasing incidence of renal cell carcinomas, as a result of more prevalent use of imaging techniques, such as ultrasonography, computed tomography and magnetic resonance imaging in recent years (Nason et al., 2014).

Ultrasonographic examination is the first imaging technique for the patients to evaluate renal cell carcinomas (Sacco et al., 2011). Ultrasonography gives information on the size, attenuation features and vascular distribution of renal masses and adds useful diagnostic information to other imaging techniques. Computed tomography is the gold standard for diagnosis, staging, and surveillance of renal cell carcinomas. Magnetic resonance imaging is usually used for patients with contrast allergy, functional renal impairment and pregnancy.

We evaluated the clinico-pathological results of the patients with renal tumours during the last 10 years period.

\section{Material and Methods}

A retrospective data on the radical or partial nephrectomy for renal tumour performed in our unit from January 2005 to January 2015 was evaluated. Patient's demographics, tumour size, TNM classification, stage and histopathology data were recorded.TNM classification is used for renal cell carcinoma (Table 1). All nephrectomy specimens were analyzed in the same pathology department. The patients were divided into two groups; group 1 includes patients who were treated between January 2005 and December 2009, group 2 those from January 2010 to January 2015. Nephron-sparing surgery was performed for lesions that are peripheral, less than $7 \mathrm{~cm}$ in size and appropriate for resection. Radical nephrectomy was performed in other cases. All patients underwent nephrectomy with open surgical techniques.

\section{Results}

Among the 325 total patients with renal tumours that were treated surgically at our clinic were included in this study. The cases increased in number progressively from 103 to 202 during the ten years period. The clinicopathological parameters of each group are shown in Table 2.

There were 103 patients in group 1. The patients were between 21 and 89 years with a mean age of 61.46 . The male patients were predominant with $66.3 \%$ of the patients and the female patients were $33.7 \%$ of the patients. Renal cell carcinomas account $83.4 \%$ of the patients, benign renal tumours were $8.7 \%$ and transitional cell carcinomas were $7.7 \%$ of the patients. The histological subtypes of renal cell carcinomas (RCCs); 64 (74.4\%) were clear cell, 12 (13.9\%) were chromophobe, $9(10.4 \%)$ were papillary and $1(1.5 \%)$ was multiloculer cystic RCC. A total of 28 (32.5\%) RCCs were classified as pT1a, 21 (24.4\%) as pT1b, 13 (15.1\%) as pT2a, $10(11.6 \%)$ as pT2b, $13(15.1 \%)$ as pT3a and $1(1.1 \%)$ as pT4. Open nephron-sparing surgery were performed for $12(11.6 \%)$ patients and the other patients were treated with open radical nephrectomy. 
Table 2 - Patient demographics and tumour characteristics of the groups

\begin{tabular}{|c|c|c|}
\hline & Group 1 & Group 2 \\
\hline Total number & 103 & 202 \\
\hline \multicolumn{3}{|c|}{ Gender } \\
\hline Male, n (\%) & $68(66.3)$ & $142(70.3)$ \\
\hline Female, n (\%) & $35(33.7)$ & $60(29.7)$ \\
\hline \multicolumn{3}{|c|}{ Tumour size $(\mathrm{cm})$} \\
\hline Mean $( \pm S D)$ & $6.66 \pm 3.65$ & $6.3 \pm 3.5$ \\
\hline \multicolumn{3}{|c|}{ Age and decades, $n(\%)$} \\
\hline Mean age $( \pm S D)$ & $61.46 \pm 13.71$ & $58.5 \pm 11.22$ \\
\hline$<30$ & $1(0.9)$ & $2(1)$ \\
\hline $30-39$ & $7(6.7)$ & $10(5)$ \\
\hline $40-49$ & $13(12.6)$ & $37(18.3)$ \\
\hline $50-59$ & $23(22.3)$ & $56(27.7)$ \\
\hline $60-69$ & $27(26.2)$ & $61(30.1)$ \\
\hline 70-79 & $24(23.3)$ & $34(16.8)$ \\
\hline $80-89$ & $8(7.7)$ & $2(1)$ \\
\hline
\end{tabular}

\begin{tabular}{lcc}
\hline \multicolumn{3}{c}{ Procedure } \\
\hline Partial, $\mathrm{n}(\%)$ & $12(11.6)$ & $47(23)$ \\
Radical, $\mathrm{n}(\%)$ & $91(88.3)$ & $157(77)$ \\
\hline & Pathological examination \\
\hline Renal cell carcinoma & $86(83.4)$ & $182(89.2)$ \\
Transitional urothelial carcinoma & $8(7.7)$ & $6(2.9)$ \\
Benign renal tumours & $9(8.7)$ & $14(6.9)$ \\
Others & & $2(1)$ \\
\hline
\end{tabular}

SD - standard deviation

There were 202 patients in group 2, 142 (70.3\%) of the patients were male, $60(29.7 \%)$ of the patients were female. The patients were between 27 and 81 years with the mean age of 58.5. Two patients had bilateral renal tumours and the number of the specimen was increased to 204. Renal cell carcinomas comprised the main bulk of the tumours with 182 (89.2\%) nephrectomy specimens. Of these tumours, 129 (70.9\%) cases were clear cell, 21 (11.5\%) were chromophobe, $21(11.5 \%)$ were papillary, 7 (3.4\%) were unclassified and there were one cases (0.5\%) with renal medullary carcinoma, mucinous tubular and spindle cell carcinoma, multilocular cystic and oncocytoid RCCs. According to the pathological classification of RCCs, 51 specimens were found as $\mathrm{pT} 1 \mathrm{a}, 54$ were $\mathrm{pT} 1 \mathrm{~b}, 13$ were pT2a, 14 were pT2b, 48 were pT3a and 2 were pT4. Comparison of TNM stage, histological subtype and nuclear grade of RCCs are shown in Table 3. Other malignant tumours; transitional urothelial carcinoma was reported in six patients, 
Table 3 - Pathological examination of the patients with renal cell carcinomas

\begin{tabular}{|c|c|c|}
\hline & Group 1 & Group 2 \\
\hline Total, n & 86 & 180 \\
\hline Male, n (\%) & $54(62.7)$ & $127(70.6)$ \\
\hline Female, n (\%) & $32(37.2)$ & $53(29.4)$ \\
\hline \multicolumn{3}{|c|}{ Pathologic T stage, $n$ (\%) } \\
\hline pT1a & $28(32.5)$ & $51(28)$ \\
\hline pT1b & $21(24.4)$ & $54(29.7)$ \\
\hline PT2a & $13(15.1)$ & $13(7.1)$ \\
\hline PT2b & $10(11.6)$ & $14(7.7)$ \\
\hline PT3a & $13(15.1)$ & $48(26.3)$ \\
\hline PT3b & $0(0)$ & $0(0)$ \\
\hline PT4 & $1(1.1)$ & $2(1)$ \\
\hline \multicolumn{3}{|c|}{$N$ stage, $n(\%)$} \\
\hline No & $84(97.6)$ & $173(95)$ \\
\hline N1 & $2(2.4)$ & 0 \\
\hline N2 & 0 & $9(5)$ \\
\hline \multicolumn{3}{|c|}{$M$ stage, $n(\%)$} \\
\hline MO & $86(100)$ & $178(98.9)$ \\
\hline M1 & 0 & $2(1.1)$ \\
\hline \multicolumn{3}{|c|}{ Stage, $n(\%)$} \\
\hline 1 & $49(57)$ & $103(56.5)$ \\
\hline ॥ & $23(26.7)$ & $24(13.2)$ \\
\hline III & $11(12.8)$ & $43(23.6)$ \\
\hline IV & $3(3.4)$ & $12(6.6)$ \\
\hline \multicolumn{3}{|c|}{ Histological subtype, $n(\%)$} \\
\hline Clear cell & $64(74.4)$ & $129(70.9)$ \\
\hline Chromophobe & $12(13.9)$ & $21(11.5)$ \\
\hline Papillary & $9(10.4)$ & $21(11.5)$ \\
\hline Multilocular cystic & $1(1.5)$ & $1(0.5)$ \\
\hline Unclassified & 0 & 7 (3.4) \\
\hline Others & 0 & $3(1.5)$ \\
\hline Nuclear grade, $n(\%)$ & $83(100)$ & 175 (100) \\
\hline G1 & $8(9.6)$ & $11(6.2)$ \\
\hline G2 & 39 (47) & $75(43)$ \\
\hline G3 & $26(31.3)$ & 72 (41.1) \\
\hline G4 & $10(12)$ & $17(9.7)$ \\
\hline
\end{tabular}

squamous cell carcinoma and rhabdomyosarcoma was diagnosed in one case in group 2. Open nephron-sparing surgery was performed for 47 (23\%) tumours and open radical nephrectomy was done for 157 (77\%) tumours. 


\section{Discussion}

Although renal cell carcinoma (RCC) represents $2-3 \%$ of all adult malignant neoplasms, it is the most lethal urologic cancer (Pantuck et al., 2000). More than $40 \%$ of the patients with RCC have died of their cancer; only $20 \%$ of mortality rate is associated with bladder and prostate cancers (Gupta et al., 2010). The incidence of small renal masses has been increased with the widespread use of imaging techniques and recent advancements (Akgül and Tinay, 2013). Nephron-sparing surgery (NSS) has been accepted as a gold standard treatment for small renal tumours, because of its comparable oncological outcome, improved survival and decreased renal insufficiency when compared with radical nephrectomy (Demirer and Yıldırım, 2013). There are some types of NSS techniques; laparoscopic, robotic or open. Open partial nephrectomy is the standard treatment for T1 tumours according to the EAU (European Association of Urology) guidelines (Ljungberg et al., 2013). The renal tumour cases were increased $96.1 \%$ and NSS was done nearly two times more in the last 5 years. The incidence of RCCs in renal tumour cases was increased in last 5 years in our study.

Patients with RCCs are usually older, with the mean age at diagnosis of 60 years (Ozbek et al., 2013). The highest incidence of this disease is found in North America and Europe. Although, the etiology of RCC is unclear, smoking, obesity, antihypertensive therapy, coffee, tea, Western diet (high in fat and protein, low vegetables and fruits) are risk factors (Chen et al., 2009). In a study from Austria, the authors found that, the median age of the patients were between 61 and 65 over the 27 years (Pichler et al., 2012). We found the mean age of the patients was 61.46 and 58.5 in the first and second 5 years.

Renal cell carcinoma is almost twice as common in men as in women (Chen et al., 2009). The male/female ratio is 1 in the population $<40$ years. The risk of RCC will be higher in young women; the studies reported relationship between RCC and some reproductive and hormonal factors such as high corporal hormone levels of young patients. The male/female ratio may be different in the studies. While this ratio was 1.9 in a study from China (Chen et al., 2009), was 1.39 in a study from Austria (Pichler et al., 2012). We found the male/female ratio was 2.13 in the patients with RCCs.

The tumour subtypes of RCCs have been published in 2004 by the World Health Organization (Dutcher, 2013). The most common subtype of RCC is clear cell that comprises $75 \%$ of all RCCs in surgical series (Cheville et al., 2003). Papillary RCCs account $15 \%$ of surgical series and chromophobe RCCs are about $5 \%$ of all RCCs. Clear cell RCCs was the most common subtype of RCCs followed by chromophope RCCs in our study. Our study found that papillary RCCs were the third most common subtype in two groups. Multilocular cystic RCC is a rare form of clear cell RCC and has a good survival (Çalıskan et al., 2011). There was only one case in the groups. 
The tumour, nodes and metastasis stage classification system is generally recommended for clinical use and has introduced significant changes based on recent literature in 2010 (Table 3) (Ljungberg et al., 2013). The patients with organ confined tumours ( $\mathrm{pT} 1$ and $\mathrm{pT} 2$ ) have decreased from 83.6 to $72.5 \%$, in the contrary, PT1b tumours were increased from 24.4 to $29.7 \%$ in our study. The authors reported that the incidence of organ confined tumour was increased from 36.9 to $73.2 \%$ during the 27 years (Pichler et al., 2012); the other study demonstrated that the percentage of organ confined tumours was 66.7, 56.2 and $65.6 \%$ in the three study group respectively (Nason et al., 2014). The patients with local advanced tumours (pT3 and pT4) have increased during the study period (from 16.2 to $27.3 \%$ ). The authors observed a decrease in pathological PT3 and PT4 RCC patients from 29.1 to $20.5 \%$ over two decades (Gupta et al., 2010). The patients with local advanced RCC have increased during the seventeen years period (from 33.3 to 34.4\%) in another study (Nason et al., 2014). One of the reasons of increasing numbers of patients with local advanced tumour: our hospital is tertiary referral centre. The other factor may be the indications of nephrectomy that has been changed during the years with surgical experience.

Fuhrman nuclear grade (based on nuclear size and shape and the prominence of nucleoli) is a prognostic factor in RCC (Gupta et al., 2010). Higher grade is associated with the biological aggressiveness and increased metastatic potential of the tumour. Most of the RCCs are classified as grade II in the studies (Pichler et al., 2012; Ozbek et al., 2013). The proportion of grade II tumours was between 43 and $61.5 \%$. There is an increasing representation of grade III and IV tumours over time, from 12.7 to $20.3 \%$ and decreasing the proportion of grade I tumours from 32 to $14.8 \%$ in an analysis of 2,739 patients (Pichler et al., 2012). Additionally, the authors reported that there was a significant increase of grade III tumours over time, from 17.6 to $30.8 \%$ and decreasing proportion of grade I tumours from 16.2 to $7.1 \%$ (Doeuk et al., 2010). On the contrary, grade III and IV tumours were decreased from 30.4 to $10.1 \%$ and from 8.5 to $4.2 \%$ in another study from India (Gupta et al., 2010). We found that most of the patients with RCC were grade II; grade III tumours were increased over the study period from 31.3 to $41.1 \%$.

The authors found an increasing representation of stage I tumours from 51 to $60 \%$, decreasing proportions of stage II and III diseases in a large retrospective American study (Kane et al., 2008). The pathological stage II and III were decreased from 14.5 to $11.6 \%$ and from 22.8 to $16.3 \%$. The pathological stage IV remained stable over the 12 year period at about $12 \%$. The investigators reported that the pathological stage III were increased from 13.9 to $21.5 \%$, stage II and IV were decreased from 18.1 to $11.1 \%$ and from 1.4 to $0.4 \%$ during the 15 years (Doeuk et al., 2010). The proportion of the pathological stage I was constant throughout the 15 year period with $67 \%$. We found that the proportions of pathological stage I tumours were similar in groups and stage II tumours were decreased from 26.7 to 
13.2\%. The pathological stage III and IV diseases were increased from 12.8 to $23.6 \%$ and from 3.4 to $6.6 \%$ in our study.

The proportion of benign renal tumours has decreased over time (from 8.7 to $6.9 \%$ ). One of the factors may be the result of the developing techniques of radiological imaging. The widespread use of cross sectional imaging has led to an increasing diagnosis of incidental and small renal lesions (Satasivam et al., 2012). Optimal management is controversial, with available options including surveillance, ablation and surgical resections. The patients may underwent surveillance or ablation therapies instead of surgery.

Renal pelvis tumours are $5-7 \%$ of all renal tumours (Ozsahin et al., 2009). The most common type is transitional cell carcinomas. Squamous cell carcinomas, adenocancers and sarcomas are rare forms. Radical surgery is essential for transitional cell carcinomas. While the incidence of these tumours was similar in group 1, less than literature in group 2 .

There are several limitations in the present study. First, the study does not include very large numbers of patients and our databases includes only pathologically diagnosed renal tumours, the patients that have been treated with minimally invasive ablation or surveillance were not included. The patients underwent surgical treatment by multiple surgeons and pathological specimens of the patients were examined different pathologist in pathology department. Despite these limitations, the present study is the largest single centre database analysis of kidney cancer stage, grade and histological changes over one decade in Turkey.

In conclusion, the percentage of partial nephrectomy has increased. The proportion of the patients with higher grades, local advanced renal cell carcinomas and stage III and IV increased during the study period. Although extensive use of imaging, epidemiologic studies are needed to define the results.

\section{References}

Akgül, H. M., Tinay, I. (2013) The biopsy of small renal masses: whom, when, how? Turkiye Klinikleri J. Urology-Special Topics 6, 24-29. (in Turkish)

Çalișkan, S., Kaya, C., Doğan, M. (2011) A rare renal tumor: Multilocular cystic renal cell carcinoma. Turkiye Klinikleri J. Urology-Special Topics 2, 68-70. (in Turkish)

Çalıșkan, S., Koca, O., Akyüz, M., Karaman, M. I. (2014) Böbrek tümörü ön tanısıyla radikal veya parsiyel nefrektomi yapılan hastalardaki benign tümörler. Yeni Üroloji Dergisi 2, 68-70.

Chen, J., Shi, B., Zhang, D., Jiang, X., Xu, Z. (2009) The clinical characteristics of renal cell carcinoma in female patients. Int. J. Urol. 16, 554-557.

Cheville, J., Lohse, C., Zincke, H., Weaver, A., Blute, M. (2003) Comparision of outcome and prognostic features among histologic subtypes of renal cell carcinoma. Am. J. Surg. Pathol. 27, 612-624.

Demirer, Z., Yıldırım, I. (2013) Surgical treatment options for small renal masses. Turkiye Klinikleri J. Urology-Special Topics 6, 46-53. (in Turkish)

Doeuk, N., Guo, D. Y., Haddad, R., Lau, H., Woo, H. H., Bariol, S., Drummond, M., Vladica, P., Brooks, A., Patel, M. I. (2010) Renal cell carcinoma: Stage, grade and histology migration over the last 15 years in a large Australian surgical series. BJU Int. 107, 1381-1385.

Çalıșkan S.; Koca O.; Akyüz M.; Öztürk M. I.; Karaman M. I. 
Dutcher, J. P. (2013) Recent developments in the treatment of renal cell carcinoma. Ther. Adv. Urol. 5, 338-353.

Gupta, N. P., Kumar, A., Dogra, P. N., Seth, A. (2010) Renal tumors presentation: Changing trends over two decades. Indian J. Cancer 3, 287-291.

Hashmi, A. A., Ali, R., Hussain, Z. F., Faridi, N. (2014) Clinicopathologic patterns of adult renal tumors in Pakistan. Asian Pac. J. Cancer Prev. 15, 2303-2307.

Kane, C. J., Mallin, K., Ritchey, J., Cooperberg, M. R., Carroll, R. P. (2008) Renal cell cancer stage migration: Analysis of the National Cancer Data Base. Cancer 113, 78-83.

Ljungberg, B., Bensalah, K., Bex, A., Canfield, S., Dabestani, S., Hofmann, F., Hora, M., Kuczyk, M. A., Lam, T., Marconi, L., Merseburger, A. S., Mulders, P. F. A., Staehler, M., Volpe, A. (2013) Guidelines on Renal Cell Carcinoma.

Nason, G. J., McGuire, B. B., Kelly, M. E., Murphy, T. M., Looney, A. T., Byrne, D. P., Mulvin, D.W., Galvin, D. J., Quinlan, D. M., Lennon, G. M. (2014) Clincopathological analysis of renal cell carcinoma demonstrates decreasing tumour grade over a 17-year period. Can. Urol. Assoc. J. 8, 125-132.

Ozbek, E., Otunctemur, A., Sahin, S., Dursun, M., Besiroglu, H., Koklu, I., Polat, E. C., Erkoc, M., Danis, E., Bozkurt, M. (2013) Renal cell carcinoma is more aggressive in Turkish patients with the metabolic syndrome. Asian Pac. J. Cancer Prev. 14, 7351-7354.

Ozsahin, M., Ugurluer, G., Zoubair, A. (2009) Management of transitional-cell carcinoma of the renal pelvis and ureter. Swiss Med. Wkly. 139, 353-356.

Pantuck, A. J., Zisman, A., Rauch, M. K., Belldegrun, A. (2000) Incidental renal tumours. Urology 56, 190-196.

Pichler, M., Hutterer, G. C., Chromecki, T. F., Jesche, J., Kampel-Kettner, K., Eberhard, K., Hoefler, G., Pummer, K., Zigeuner, R. (2012) Trends of stage, grade, histology and tumor necrosis in renal cell carcinoma in a European centre surgical series from 1984 to 2010. J. Clin. Pathol. 65, 721-724.

Sacco, E., Pinto, F., Totaro, A., D’Adressi, A., Racioppi, M., Gulino, G., Volpe, A., Marangi, F., D’Agostino, D., Bassi, P. (2011) Imaging of renal cell carcinoma: Stage of the art and recent advances. Urol. Int. 86, 125-139.

Satasivam, P., Sengupta, S., Rajarubendra, N., Chia, P. H., Munshey, A., Bolton, D. (2012) Renal lesions with low R.E.N.A.L nephrometry score associated with more indolent renal cell carcinomas (RCCs) or benign histology: finding in an Australian cohort. BJU Int. 109, 44-47 (Suppl. 3). 